\title{
THE FAMILY OF HATTON
}

BEING CHIEFLY LETTERS ADDRESGED TO

CHRISTOPHER FIRST VISCOUNT HATTON

A.D. $1601-1704$.

EDITED BY

EDWARD MAUNDE THOMPSON.

VOLUME II.

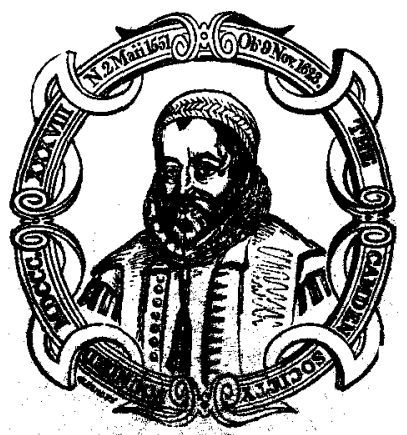

PRINTED FOR THE CAMDEN SOCIETY. spoco,kexyrir. 
WESTMINSTER :

PRINTED BY NICHOLS AND BUNS

25, PARLIAMHAT STREET.

[NEW SERIES XXIII.] 


\section{COUNCIL OF THE CAMDEN SOCIETY}

FOR THE YEAR 1878-79.

\section{President,}

THE RIGHT HON. THE EARL OF VERULAM, F.R.G.S.

WILLIAM CHAPPELL, ESQ. F.S.A., Treasurer.

HENRY CHARLES COOTE, ESQ. F.S.A.

F. W. COSENS, ESQ.,

JAMES GAIRDNER, ESQ.

SAMUEL RAWSON GARDINER, ESQ., Director.

WILLTAM GILBERT, ESQ.

WILLIAM OXENHAM HEWLETT, ESQ., F.S.A.

ALFRED KINGSTON, ESQ., Secretary.

FREDERIC OUVRY, ESQ. Pres. S.A.

THE FARL OF POWIS, LL.D.

JAMES SPEDDING, ESQ.

WILLIAM JOHN THOMS, ESQ. F.S.A.

J. R. DANIEL-TYSSEN, ESQ. F.S.A.

THE DEAN OF WESTMINSTER, D.D., V.P.S.A.

SIR ALBERT W. WOODS, Garter King of Arms, F.S.A. 
The Council of the Campen Societry desire it to be understoyd that they are not answerable for any opinions or abservations that may appear in the Society's publications; the Editors of the several Works being alone responsible for the same. 